\title{
Physicochemical characteristics of canned vegetable-type soybean processed with zinc at different pasteurization times
}

\author{
Karina Czaikoski(1), Rodrigo Santos Leite ${ }^{(2)}$, José Marcos Gontijo Mandarino(2), \\ Mercedes Concórdia Carrão-Panizzi( ${ }^{(3)}$, Josemeyre Bonifácio Da Silva ${ }^{(4)}$ and Elza louko Ida ${ }^{(4)}$
}

\begin{abstract}
(1)Universidade Estadual do Centro-Oeste, Departamento de Engenharia de Alimentos, Campus Cedeteg, Rua Simeão Varela de Sá, no 03, VilaCarli,CEP85040-080Guarapuava,PR,Brazil.E-mail:karinelka@yahoo.com.br ${ }^{(2)}$ EmbrapaSoja, RodoviaCarlosJoãoStrass, AcessoOrlando Amaral, Distrito Warta, Caixa Postal 231, CEP 86001-970 Londrina, PR, Brazil. E-mail: rsleite@embrapa.br, josemarcos.gontijo@embrapa.br (3)Embrapa Trigo, BR-285, Km 294, Caixa Postal 451, CEP 99001-970 Passo Fundo, RS, Brazil. E-mail: mercedes.panizzi@embrapa.br (4)Universidade Estadual de Londrina, Departamento de Ciência e Tecnologia de Alimentos, Campus Universitário, Rodovia Celso Garcia Cid, Km 380, Caixa Postal 10.011, CEP 86057-970 Londrina, PR, Brazil. E-mail: josibonifacio@uel.br, elida@uel.br
\end{abstract}

\begin{abstract}
The objective of this work was to evaluate the effects of zinc concentration in acidified brine and of pasteurization time on the zinc content, color, and physicochemical and microbiological characteristics of canned vegetable-type soybean (Glycine max). The $2^{2}$ central composite rotational design (CCRD) was used, with zinc concentration in the acidified brine and duration of pasteurization as variables, resulting in 12 assays. A canning formulation was developed and compared with canned-vegetable type soybean without zinc and with fresh-vegetable type soybean, with microbiological evaluation. Zinc addition within the limits defined by Food and Drug Administration ( $\leq 75 \mathrm{ppm}$ ) does not affect the physicochemical and microbiological characteristics of canned grains, subjected to $10 \mathrm{~min}$ pasteurization. Acidified brine containing zinc increases the content of isoflavone glycosides, decreases the content of malonyl glycosides, and has lower-sucrose and stachyose contents than fresh grains. Zinc addition does not significantly influence the color of grains.

Index terms: Glycine max, edamame, isoflavones, oligossacharides, thermal processing.

\section{Características físico-químicas de soja tipo vegetal em conserva, processada com zinco em diferentes tempos de pasteurização}

\begin{abstract}
Resumo - O objetivo deste trabalho foi avaliar os efeitos da concentração de zinco na salmoura acidificada e do tempo de pasteurização sobre o teor de zinco, a coloração e as características físico-químicas e microbiológicas da soja (Glycine max) do tipo vegetal em conserva. Utilizou-se um delineamento composto central rotacional $2^{2}$, cujas variáveis foram a concentração de zinco na salmoura e o tempo de pasteurização, o que resultou em 12 ensaios. Uma formulação de conserva foi desenvolvida e comparada com grãos em conserva sem adição de zinco e com grãos frescos, com avaliação microbiológica. A adição de zinco dentro dos limites definidos pela Food and Drug Administration ( $\leq 75 \mathrm{ppm})$ não afeta as características físico-químicas e microbiológicas dos grãos em conserva submetidos a 10 min de pasteurização. A salmoura acidificada e com adição de zinco aumenta o conteúdo de glicosídeos isoflavonas, diminui o conteúdo de malonil glicosídeos e tem menores conteúdos de sacarose e estaquiose do que grãos frescos. A adição de zinco não influencia significativamente a coloração dos grãos.
\end{abstract}

Termos para indexação: Glycine max, edamame, isoflavonas, oligossacarídeos, processamento térmico.

\section{Introduction}

Vegetable-type soybean, also called edamame, play an important role in the food culture of Japan and other Asian countries. Usually, vegetable-type soybeans have large seed and are harvested at the R6 stage, around 6-7 weeks after flowering (Sugimoto et al., 2010; Saldivar et al., 2011). According to Hou et al. (2011), the nutritional quality of vegetable-type soybean is determined by its protein content, as well as by the amount of unsaturated fatty acids, minerals, vitamins, isoflavones, and other trace nutrients. In addition to their nutritional value, vegetable-type soybeans have a sweet taste that can be attributed to the high content of sucrose (Saldivar et al., 2011).

Vegetable-type soybeans can be processed and used as snacks or salads. In general, the pods are boiled and beans are consumed with or without salt (Sugimoto et al., 2010). However, this type of soybean food is highly perishable. To extend their shelf life, they are subjected to bleaching and cold storage (Xu et al., 2012). Another alternative to increase the
Pesq. agropec. bras., Brasília, v.53, n.7, p.840-848, July 2018 DOI: 10.1590/S0100-204X2018000700008 Creative Commons Attribution 4.0 International License 
use of vegetable-type soybeans is canning, which would afford a new opportunity to expand and market soybean products (Mozzoni et al., 2009). In addition, canned vegetable-type soybeans containing zinc in brine have not yet been investigated, hence, canning may be an interesting alternative to maintain their physicochemical characteristics.

Texture, color, and enzyme activities are the main characteristics that should to be maintained in case of canned vegetables (Wang \& Chang, 1988). However, during the thermal processing of canned vegetables, the color and firmness may generally be lost. To preserve the green color, $\mathrm{pH}$ control, change in enzyme activity, and addition of various types of additives have been used (Wang \& Chang, 1988; McGlynn et al., 1993). The use of $\mathrm{ZnCl}_{2}$ in an aqueous medium to bleach vegetables, followed by different thermal treatments, has been employed to retain the green color (Ngo \& Zhao, 2007; Damodaran et al., 2010; Zheng et al., 2014). For the inactivation of lipoxygenases, it is recommended that vegetable soybeans should be bleached; bleaching was carried for 90 s prior to heat treatment. The expected microbial lethality of the heat treatment of vegetable soybean using brine containing $\mathrm{NaCl}\left(150 \mathrm{~g} \mathrm{~L}^{-1}\right)$ and $\mathrm{CaCl}_{2}\left(2.9 \mathrm{~g} \mathrm{~L}^{-1}\right)$, and $\mathrm{pH}$ of 6.5 was observed after $4 \mathrm{~min}$, which was sufficient for the 12-log reduction required for low-acid foods and, at the same time, retaining desirable colour and texture (Mozzoni et al., 2009). Czaikoski et al. (2013) evaluated the color and isoflavone content of canned vegetable-type soybeans in acidified brine, after the addition of sucrose and different pasteurization times. They observed that the addition of sucrose helped to maintain the color, while the thermal treatment increased the content of isoflavone glycosides, reduced the content of malonylglycoside, and was unable to convert isoflavone glycosides to aglycones.

The objective of this work was to evaluate the effects of zinc concentration in acidified brine and the pasteurization time on the zinc content, color, and physicochemical and microbiological characteristics of canned vegetable-type soybeans.

\section{Materials and methods}

Pods of the cultivar BRS 267 (vegetable-type soybeans) harvested at the R6 growth stage, when seeds are completely developed, but immature, were supplied by Embrapa Soja, located in the municipality of Londrina, in the state of Paraná, Brazil (soybean season 2009/2010). Canned vegetable-type soybean in acidified brine was prepared according to Czaikoski et al. (2013) by using zinc acetate instead of sucrose. Different amounts of zinc acetate were added according to the experimental design (Table 1). Glass containers for canned vegetable-type soybean were closed with metal caps and pasteurized in boiling water over specified times in the experimental design. After a quick cooling with water, glasses of the canned vegetable-type soybean were stored in closed cardboard boxes at room temperature $\left(25^{\circ} \mathrm{C}\right)$ for 30 days.

A central composite rotational design (CCRD) with a $2^{2}$ factorial, four axial points, and four replicates at the central point, in a total of 12 randomized assays, was used to evaluate the effects of zinc and pasteurization time on canned soybeans. The experimental design matrix, as well as the coded and real values of the independent variables $\left[\mathrm{X}_{1}\right.$ (ppm of zinc in acidified brine) and $\mathrm{X}_{2}$ (pasteurization time in minutes)] are shown in Table 1.

After 30 days of storage, the response functions were determined: $Y_{1}=$ zinc $(\mathrm{ppm})$ in acidified brine, and $\mathrm{Y}_{2}$ $=$ degree of chromatic hue of soybeans. The software program Statistica version 7.0 (Statsoft Inc. 2004, Tulsa, USA) was used for the multiple regression analysis and for the response surface model. The model for each response was expressed by the equation $Y=\beta_{0}+\beta_{1} x_{1}$ $+\beta_{2} x_{2}+\beta_{11} x_{1}^{2}+\beta_{22} x_{2}^{2}+\beta_{12} x_{1} x_{2}+\varepsilon$, in which: $Y$ is the response; $x_{1}$ and $x_{2}$ are levels of the coded variables; $\beta$ is the estimated coefficient on the response surface, and $\varepsilon$ is the pure error.

After the analysis of the response surface and under optimum conditions, the proposed model was validated by the quadruplicate preparation of the optimized canning process. After validation of the optimum conditions of the studied variables, a formulation was developed for canned vegetable-type soybeans and the control (canned vegetable-type soybeans in brine without zinc, but with sodium chloride, calcium chloride, and citric acid). Canned soybeans with zinc, without zinc (control), and fresh soybean grains were evaluated to determine their microbiological, physical, and chemical characteristics. Using the software program Statistica version 7.0 (Statsoft Inc. 2004, Tulsa, USA), the results, which were the mean values 
of three replicates, were compared using the analysis of variance and the Tukey's test, at 5\% probability.

The commercial sterility test was conducted to guarantee the microbiological control of canned food, as described by Silva et al. (2007). After 30 days, each container with acidified brine was opened aseptically, and samples were incubated anaerobically and aerobically in Bacillus thermoacidurans broth (TAB), malt extract (ME), and Man Rogosa and Sharpe broth (MRS); each medium was maintained at 35 and $55^{\circ} \mathrm{C}$ for 5 days. The obtained qualitative results were based on a visual evaluation of the turbidity of the medium and gas formation.

The color measurements were performed by using photographs taken with a camera (Canon EOS Digital Rebel XT) with a lens of $50 \mathrm{~mm}$ focal length (Oliveira et al., 2003). Digital images of 3456x2304 pixels resolution were obtained as bitmap (BMP) files using the Microsoft Paint Program, version 6.0. The digital images were converted from BMP values (color-read pixel by pixel) into RGB (red-green-blue) files using the program RGB Medium Color Converter for BMP Images (Sacks et al., 2002), and these values were converted to the Cielab system using the Munsell Conversion program (version 4.01) to obtain the parameters L* (luminosity), a* (red-green component), and $b^{*}$ (yellow-blue component). To assess the grain color, the hue parameters, $\mathrm{H}^{*}=\operatorname{arc}$ tang $\left(\mathrm{b}^{*} / \mathrm{a}^{*}\right)$, were calculated according to Lawless \& Heymann (1998).
Grain hardness was evaluated using a TA-XT2i texturometer (Stable Micro Systems, London, UK). The samples were compressed to $25 \%$ of their initial height by an aluminum cylinder probe (P25 L with a $2.5 \mathrm{~mm}$ diameter) at $0.05 \mathrm{~N}$, using a compression cycle at $1 \mathrm{~mm} \mathrm{~s}^{-1}$ constant speed.

Fresh grains of vegetable-type soybeans and those that were canned in acidified brine, with or without zinc, were lyophilized (Liobras, L-10, São Carlos, SP, Brazil), and ground in a CBG100W analytical mill (Black and Decker, Uberaba, MG, Brazil), to obtain a fine powder (35 mesh).

The zinc content and the chemical composition were determined in triplicate (AOAC International, 2016), and the average results were expressed $\mathrm{g} 100 \mathrm{~g}^{-1}$.

Isoflavones were extracted according to CarrãoPanizzi et al. (2002), and quantified using the methodology proposed by Berhow (2002). The methodology utilized high-performance liquid chromatography (HPLC) (Model 2690, Waters, USA), with a reversed-phase ODS C18 column YMC-Pack ODS-AM S-5 mm, 120 a, with $4.6 \mathrm{~mm}$ diameter, and $250 \mathrm{~mm}$ length (YMC Europe GMBH, Dinslaken, Deutschland), and a photodiode-array detector model 996 (Waters Co., Milford, MA, USA) adjusted to 254 $\mathrm{nm}$ wavelength. A linear binary gradient system with methanol, trifluoroacetic acid, and ultrapure deionized water was used for separation. The initial gradient was $20 \%$, reaching $80 \%$ after $35 \mathrm{~min}$, and returning to $20 \%$

Table 1. Central composite rotational design $2^{2}$ factorial, with coded and real values of independent variables and response functions $(\mathrm{Y})$.

\begin{tabular}{|c|c|c|c|c|c|c|}
\hline \multirow[t]{3}{*}{ Assays } & \multicolumn{6}{|c|}{ Coded (real) } \\
\hline & \multirow{2}{*}{$\frac{\text { Zinc brine }(\mathrm{ppm})}{\mathrm{x}_{1}\left(\mathrm{X}_{1}\right)}$} & \multirow{2}{*}{$\begin{array}{c}\text { Pasteurization time (min) } \\
\mathrm{x}_{2}\left(\mathrm{X}_{2}\right) \\
\end{array}$} & \multicolumn{4}{|c|}{ Response Functions (Y) } \\
\hline & & & $\mathrm{Y}_{1}$ & $\hat{\mathrm{Y}}_{1}$ & $\mathrm{Y}_{2}$ & $\hat{\mathrm{Y}}_{2}$ \\
\hline 1 & $-1(95)$ & $-1(14)$ & 194.33 & 181.83 & 92.72 & 92.75 \\
\hline 2 & $-1(95)$ & $+1(36)$ & 185.67 & 195.79 & 92.02 & 92.41 \\
\hline 3 & $+1(431)$ & $-1(14)$ & 675.00 & 662.42 & 93.01 & 93.19 \\
\hline 4 & $+1(431)$ & $+1(36)$ & 653.00 & 663.06 & 92.90 & 92.85 \\
\hline 5 & $-1.41(26)$ & $0(25)$ & 84.53 & 85.71 & 92.70 & 92.69 \\
\hline 6 & $+1.41(500)$ & $0(25)$ & 754.67 & 755.94 & 93.12 & 93.31 \\
\hline 7 & $0(263)$ & $-1.41(10)$ & 408.33 & 425.56 & 92.87 & 92.85 \\
\hline 8 & $0(263)$ & $+1.41(40)$ & 450.67 & 435.89 & 92.47 & 92.37 \\
\hline 9 & $0(263)$ & $0(25)$ & 407.00 & 428.17 & 93.03 & 93 \\
\hline 10 & $0(263)$ & $0(25)$ & 417.67 & 428.17 & 92.92 & 93 \\
\hline 11 & $0(263)$ & $0(25)$ & 449.33 & 428.17 & 92.95 & 93 \\
\hline 12 & $0(263)$ & $0(25)$ & 438.67 & 428.17 & 93.11 & 93 \\
\hline
\end{tabular}

Experimental Y1, ppm of zinc in the brine; estimated $\hat{Y} 1$, using the proposed model; experimental Y2, chromatic hue degree; and estimated $\hat{Y} 2$, using the proposed model. 
after $40 \mathrm{~min}$. The mobile-phase flow rate was $1 \mathrm{~mL}$ per min, and the temperature during the separation was maintained at $25^{\circ} \mathrm{C}$. The quantification was performed using external standard calibration curves of daidzin, genistin, glycitin, daidzein, genistein, glycitein, malonyldaidzin, malonylgenistin, malonylglycitin, acetyldaidzin, acetylgenistin, and acetylglycitin (purchased from Sigma Chemicals Co., St. Louis, MO, USA). The isoflavone contents were expressed as a molar basis, and as milligrams of isoflavone per 100 grams of sample on a dry basis.

Sample sugar contents were determined according to Masuda et al. (1996) and Oliveira et al. (2010), using ion-exchange chromatography ED 50 Dionex Bio LC (Thermo Scientific, Sunnyvale, CA, USA) with an amperometric detector, $\mathrm{AgCl}$ electrode ED 50 Dionex Bio LC (Thermo Scientific, Sunnyvale, CA, USA USA), amperometric gold cell, and sample selfinjector. A CarboPac PA 10 column $(250 \mathrm{~mm}$ length $\times 4 \mathrm{~mm}$ internal diameter, and $5 \mu \mathrm{m}$ particles) was used to separate sugars. The analyses were conducted using an isocratic system, with $50 \mathrm{mmol} \mathrm{L}^{-1} \mathrm{NaOH}$ solution as the mobile phase at a $1.0 \mathrm{~mL}$ per min flow rate at $25^{\circ} \mathrm{C}$. The quantification (gram of sugars per $100 \mathrm{~g}$ of sample, on a dry basis) was performed using the external standard curves for calibration-standard sugars (Wako Mark, Japan). All reagents used were analytical grade HPLC.

\section{Results and discussion}

According to the regression parameters, the variable $X_{1}$ (ppm zinc in the acidified brine) exhibited a significant linear and positive effect $\left(\beta_{0}=236.96\right.$, $\mathrm{p}<0.05)$ in the response function $Y_{1}(\mathrm{ppm}$ zinc in the acidified brine of canned vegetable-type soybeans), whereas other effects were not significant. Considering the effect of variable $\mathrm{X}_{1}$ only, the mathematical model can be described as $\hat{Y}_{1}=428.17+236.96 x_{1}$. The lack-of-fit of the model was not significant (at $95 \%$ ), and $99.47 \%\left(\mathrm{R}^{2}\right)$ of the experimental data was properly adjusted to the model. From the regression coefficients, it can be estimated that the increase of zinc concentration $\left(\mathrm{x}_{1}\right)$ from -1 to +1 in the acidified brine caused an increase of 3.5 times the zinc content of the canned vegetable-type soybeans. These results were estimated, but to meet the limit of $<75 \mathrm{ppm}$ of zinc in the final product, which was established by the Food and Drug Administration (FDA) (Federal Register, 1986), a mathematical model was established to predict the appropriate concentration of zinc to be added to the brine. From the regression analysis and the analysis of variance, the simple linear regression model (Figure 1A) was built, in which $\mathrm{Y}_{1}$ increase
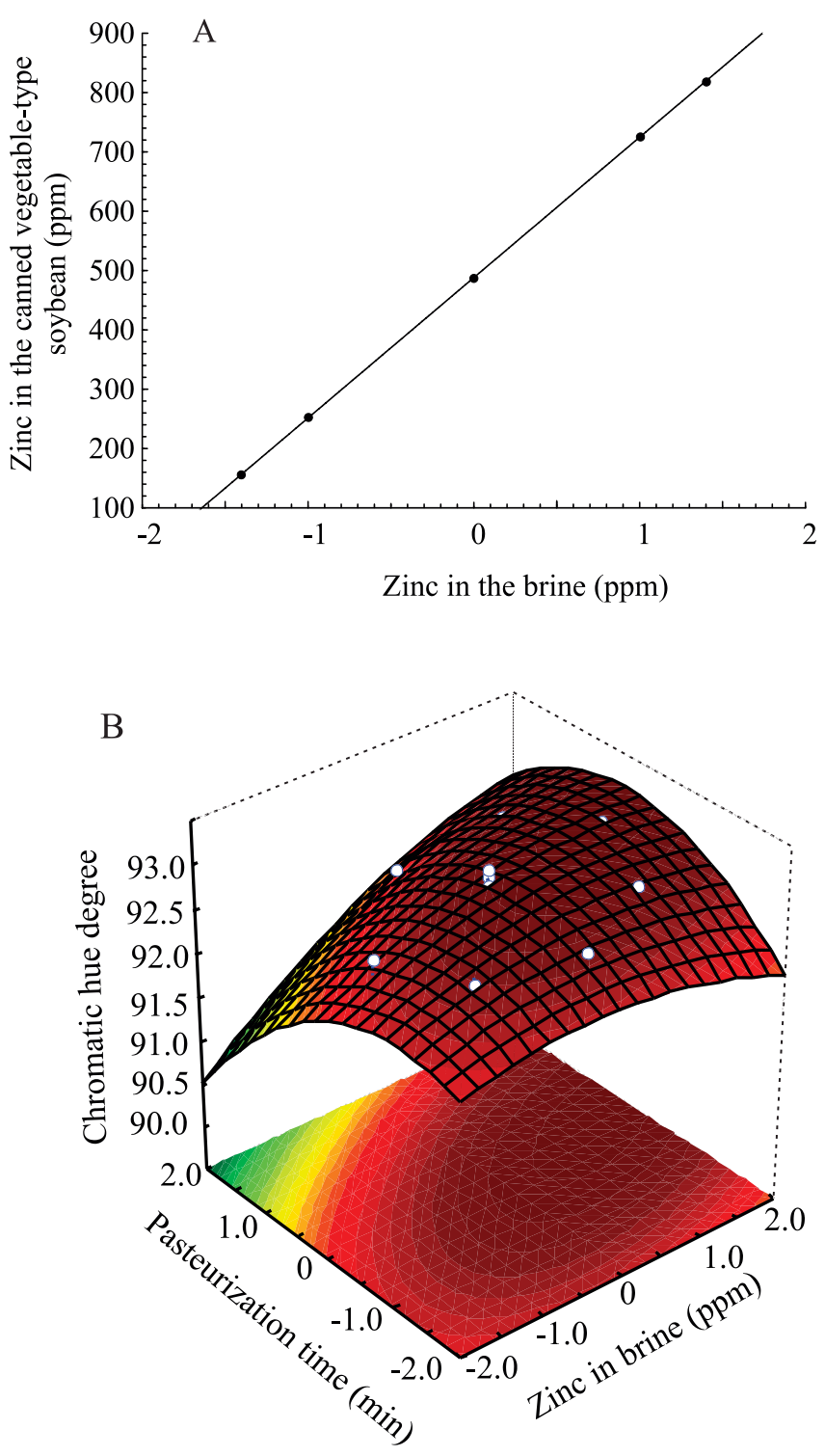

93

92.5

92

91.5 91

Figure 1. Linear regression model for zinc in the acidified brine of canned vegetable-type soybeans according to the zinc content in the brine (A). Response surface chromatic hue degree for canned vegetable-type soybean, as a function of zinc in the acidified brine and pasteurization time (B). 
was followed by $X_{1}$ increase, and was independent of $X_{2}$. Therefore, there was a region where $Y_{1}$ was a maximum (800 ppm $\mathrm{Zn}$ in the canned grains), whose $\mathrm{Zn}$ content exceeded $75 \mathrm{ppm}$ in the final product.

Among the 12 assays, the assay five $\left[\left(\mathrm{x}_{1}=-1.41\right.\right.$, or $\mathrm{X}_{1}=26 \mathrm{ppm}$ of zinc), and $\left(\mathrm{x}_{2}=0\right.$, or $\mathrm{X}_{2}=25 \mathrm{~min}$ of pasteurization)] had the lowest-zinc content, that is, $\hat{Y}_{1}=84.53 \pm 2.45 \mathrm{ppm}$ of zinc in canned vegetabletype soybeans (Table 1). However, the maximum limit of $75 \mathrm{ppm}$ zinc in canned grains is below that of the investigated region, and according to the mathematical model, it can be estimated that when $\mathrm{x}_{1}=-1.5$, or $\mathrm{X}_{1}=$ $10.91 \mathrm{ppm}$ of the zinc, the response function $\hat{Y}_{1}$ will be equal to $73.49 \mathrm{ppm}$ of zinc in canned soybeans, irrespectively of the pasteurization time. Therefore, when preparing canned grains, a shorter pasteurization time (10 min) was applied because the variable $\left(\mathrm{X}_{2}\right)$ had no significant effect on $Y_{1}$, and this approach would be suitable for the development of commercially sterile canned grains.

After establishing the condition with lowerzinc content, the proposed model was validated by performing the quadruplicate assay. The experimental response $\left(\mathrm{Y}_{1}\right)$ was equal to $72.74 \mathrm{ppm}$ of zinc in canned soybeans. The model error was $1.02 \%$, indicating that the experimental results showed a good fit to the proposed model and can be used as a predictive tool.

As to the response function $\mathrm{Y}_{2}$ (chromatic hue degree of canned vegetable-type soybeans), according to the regression parameters, the variable $X_{1}$ ( $p$ pm zinc in the acidified brine) exhibited a significant linear and positive effect $\left(\beta_{1}=0.22, \mathrm{p} \leq 0.05\right)$; the variable $\mathrm{X}_{2}$ exhibited a significant linear, quadratic, and negative effect $\left(\beta_{2}=-0.17, \beta_{22}=-0.20, p \leq 0.05\right)$, and the interaction $\mathrm{X}_{1} \mathrm{X}_{2}$ was significant and positive $\left(\beta_{12}=0.14, \mathrm{p} \leq 0.05\right)$. Only the quadratic effect of $X_{1}$ was not significant $\left(\beta_{11}=-0.08, \mathrm{p} \leq 0.05\right)$. Considering only the significant variables, the mathematical model was described as $\hat{\mathrm{Y}}_{2}=93+0.22 \mathrm{x}_{1}-0.17 \mathrm{x}_{2}-0.20 \mathrm{x}^{2}+0.14 \mathrm{x}_{1} \mathrm{x}_{2}$. The lackof-fit was not significant at $95 \%$, and $90.64 \%\left(\mathrm{R}^{2}\right)$ of the experimental data were properly adjusted to the model. A response surface was constructed based on the $\hat{Y}_{2}$ response function (Figure $1 \mathrm{~B}$ ). A region where $\hat{Y}_{2}$ was a maximum and equal to $93^{\circ}$ was observed; however, the optimal point for this model was dependent on the model $\left(\hat{\mathrm{Y}}_{1}\right)$ proposed earlier because the zinc concentration in the product should not exceed the limit set by the FDA (Federal Register,
1986). After establishing that $\mathrm{x}_{1}=-1.5, \mathrm{x}_{2}=-1.41$, and $\hat{\mathrm{Y}}_{2}=92.81^{\circ}$ for the chromatic hue of canned vegetabletype soybeans, the model was validated by conducting the assay in quadruplicate. The obtained experimental response $\left(\mathrm{Y}_{2}\right)$ was $92.86^{\circ}$ for the chromatic hue of canned vegetable-type soybeans. The error model was $0.05 \%$, indicating that the experimental results showed a good fit to the proposed model, and can be used for predictive purposes.

According to the Technical Report $\mathrm{n}^{\circ} 64$ of the Brazilian Health Regulatory Agency - ANVISA (2014), zinc acetate is one of the mineral substances approved for use in foods. Thus, the conditions required for the formulation of canned vegetable-type soybeans with a suitable zinc content and better color were established as $10 \mathrm{~min}$ of pasteurization in a brine containing zinc acetate (10.91 ppm), sodium chloride solution (6 g $\left.100 \mathrm{~mL}^{-1}\right)$, calcium chloride $(0.29 \mathrm{~g}$ $\left.100 \mathrm{~mL}^{-1}\right)$, and citric acid (pH 3.9).

Results from the microbiological analyzes, showed that canned vegetable-type soybeans were safe and could be consumed without any health risk.

When subjected to heat, vegetables have their bright green changed to a dull olive-brown color owing to the conversion of chlorophyll into pheophytin. This change is undesirable for consumers, but is quite common for several product types (Damodaran et al., 2010). From our results, fresh grains showed the highest value for the degree of chromatic hue parameter $\left(121.17^{\circ} \pm 0.21\right)$ (Table 2), in comparison to canned soybean grains, with zinc acetate, or without zinc (control). The degree of chromatic hue of zinc-canned grains $(92.86 \pm 0.05)$ compared to that of the control $(92.34 \pm 0.25)$ was similar, which shows that the concentration in which zinc was added did not significantly influence the coloring of the grains, as reported in many studies which showed that zinc ions are effective in maintaining green color (Ngo \& Zhao, 2007; Damodaran et al., 2010; Zheng et al., 2014). According to Lawless \& Heymann (1998), the chromatic hue has cylindrical coordinates that indicate the location of the color in a diagram, in which the angles indicates colors as follows: $0^{\circ}$ indicates pure red; $90^{\circ}$, pure yellow; $180^{\circ}$, pure green; and $270^{\circ}$, pure blue). The color of the canned and fresh grains remained between yellow and pure green, and processing accentuated this tendency.

Fresh grains showed the highest-hardness values $(73.33 \pm 1.82 \mathrm{~N})$, and no differences were observed 
between canned grains with zinc $(54.98 \pm 1.05 \mathrm{~N})$ and the control $(56.93 \pm 0.39 \mathrm{~N})$ (Table 2). In general, vegetables lose their firmness during heat processing because there are several chemical changes in the vegetable tissue, such as the hydrolysis of pectic materials, gelatinization of starch, and the partial solubilization of hemicellulose (Fellows, 2016).

After thermal treatment, the grains of the vegetabletype soybeans showed a reduction in the concentration of lipids (Table 2), which is most likely due to the applied heat and the low $\mathrm{pH}$, which may cause hydrolysis of triacylglycerol (Damodaran et al., 2010). The highestash content was observed in the canned soybeans with

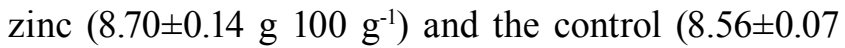
$\left.\mathrm{g} 100 \mathrm{~g}^{-1}\right)$, which may be due to the absorption of chloride and sodium from the brine (Fellows, 2016). Fresh vegetable-soybean grains had the highest-

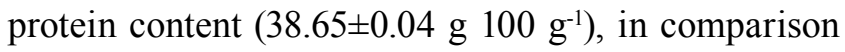
with those of canned grains with zinc $(35.86 \pm 0.38 \mathrm{~g}$

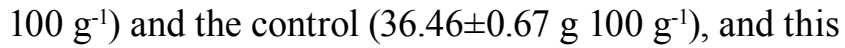
difference may be due to the denaturing effect of heat, which is more pronounced in the presence of water (Damodaran et al., 2010). No differences were observed in the carbohydrate content among all treatments.

Canned grains, either with or without zinc, showed the highest total concentration of daidzin isoflavone $\left(6.51 \pm 0.32\right.$ and $6.39 \pm 0.34 \mathrm{mg} 100 \mathrm{~g}^{-1}$ of sample on a dry basis, respectively), in comparison with that in the fresh grains (2.21 $\left.\pm 0.09 \mathrm{mg} 100 \mathrm{~g}^{-1}\right)$ (Table 3). Heat processing increased the content of isoflavone glycosides (daidzin, genistin, and glycitin), and reduced the content of malonylglycosides (malonyldaidzin, malonylglycitin, and malonylgenistin) in comparison with canned-fresh grains (Table 3). A similar behavior was observed in the study by Andrade et al. (2016), in which the treatment of whole soybean flour at $200^{\circ} \mathrm{C}$ for $20 \mathrm{~min}$ resulted in a higher conversion of malonylglycosides to acetylglycosides, $\beta$-glycosides, and aglycones. According to Kudou et al. (1991), these forms of isoflavones can also be produced by the decarboxylation of malonyl during heat treatment. The acetyl forms of isoflavones were not detected in the canned vegetabletype soybeans owing to the wet heat treatment. The canned grains in acidified brine with zinc showed low levels of daidzein $\left(0.22 \pm 0.01 \mathrm{mg} 100 \mathrm{~g}^{-1}\right.$ of sample on a dry basis), which indicates that the thermal processing was insufficient to convert the isoflavone glucosides to aglycones. These results are in accordance with those described by Andrade et al. (2016) and Yue et al. (2010), who observed that the conversion of daidzin, acetyldaidzin, and malonidazidin to daidzein occurs only after more severe heat treatments. Fresh grains exhibited the highest content of total isoflavones (51.87 $\pm 0.64 \mathrm{mg} 100 \mathrm{~g}^{-1}$ of sample on a dry basis), in comparison with canned grains with or without zinc (45.26 \pm 1.66 and $44.66 \pm 0.68 \mathrm{mg} 100 \mathrm{~g}^{-1}$ of sample on a dry basis, respectively). According to Lima et al. (2014), the leaching and degradation of isoflavones can occur at soaking temperatures above $25^{\circ} \mathrm{C}$. Isoflavones have important health benefits to humans by reducing the risk of various diseases, including breast cancer and prostate cancer (Hsu et al., 2010; Dong et al., 2013; Wada et al., 2013).

Besides the maintenance of color and texture, it is important to consider the sweetness because, according to Saldivar et al. (2011), a high-sucrose content is desirable in vegetable-type soybeans. Canned soybeans containing zinc had a lower-glucose and fructose content than the control. In fresh grains, sucrose and stachyose were higher than in canned soybean grains with zinc or the control (Table 4). Thermal processing in an acidic solution may have promoted the hydrolysis of the sucrose and stachyose of the canned soybeans with zinc (Damodaran et al.,

Table 2. Degree of chromatic hue and hardness, and chemical composition of vegetable-type soybean canned with zinc, or canned without zinc, or with fresh soybean grains.

\begin{tabular}{|c|c|c|c|c|c|c|}
\hline Sample & Degree of chromatic hue & Hardness $(\mathrm{N})$ & Lipids $^{(3)}$ & $\operatorname{Ash}^{(3)}$ & Proteins $^{(3)}$ & Carbohydrates $^{(3)}$ \\
\hline Canned with zinc ${ }^{(1)}$ & $92.86 \pm 0.05 \mathrm{~b}$ & $54.98 \pm 1.05 \mathrm{~b}$ & $20.41 \pm 0.50 \mathrm{~b}$ & $8.70 \pm 0.14 \mathrm{a}$ & $35.86 \pm 0.38 \mathrm{~b}$ & $35.04 \pm 0.83 \mathrm{a}$ \\
\hline Control (without zinc) ${ }^{(2)}$ & $92.34 \pm 0.25 b$ & $56.93 \pm 0.39 b$ & $20.25 \pm 0.42 b$ & $8.56 \pm 0.07 \mathrm{a}$ & $36.46 \pm 0.67 \mathrm{~b}$ & $34.71 \pm 0.97 \mathrm{ab}$ \\
\hline Fresh soybean grains & $121.17 \pm 0.21 \mathrm{a}$ & $73.33 \pm 1.82 \mathrm{a}$ & $22.80 \pm 0.34 \mathrm{a}$ & $5.57 \pm 0.28 \mathrm{~b}$ & $38.65 \pm 0.04 \mathrm{a}$ & $32.90 \pm 0.15 b$ \\
\hline
\end{tabular}

(1)Brine with $\mathrm{NaCl}_{2}, \mathrm{CaCl}_{2}$, citric acid, and zinc acetate; (2)brine with $\mathrm{NaCl}_{2}, \mathrm{CaCl}_{2}$, and citric acid; (3)results expressed (g $\left.100 \mathrm{~g}^{-1}\right)$ on a dry basis. $\mathrm{Mean}^{2}$ values followed by the same letters in the columns do not differ, by Tukey's test, at $5 \%$ probability. 
2010). Mozzoni et al. (2009) observed that the sucrose content initially increased within $5 \mathrm{~min}$ of thermal processing, and did not change with processing time.

Canned vegetable soybean grains are products with extended shelf lives, and they should be well processed in order to show high-quality attributes, such as hardness, color, and sweet taste. From the results, the addition of zinc to brine, in concentrations that are within the maximum limit established by the FDA, did not benefit the physical or chemical quality of canned grains. Therefore, the best conditions for canned vegetable-type soybean grains (or edamame)

Table 3. Content of different forms of isoflavones of vegetable-type soybean canned with zinc, or canned without zinc, or with fresh soybean grains.

\begin{tabular}{lccr}
\hline Isoflavone $^{(1)}$ & $\begin{array}{c}\text { Canned with } \\
\text { zinc }^{(2)}\end{array}$ & $\begin{array}{c}\text { Control } \\
\text { (without zinc) }^{(3)}\end{array}$ & $\begin{array}{c}\text { Fresh } \\
\text { soybean grains }\end{array}$ \\
\hline Daidzin & $6.51 \pm 0.32 \mathrm{a}$ & $6.39 \pm 0.34 \mathrm{ab}$ & $2.21 \pm 0.09 \mathrm{c}$ \\
Glicitin & $3.41 \pm 0.30 \mathrm{a}$ & $3.61 \pm 0.15 \mathrm{a}$ & $2.41 \pm 0.31 \mathrm{~b}$ \\
Genistin & $5.96 \pm 0.32 \mathrm{a}$ & $6.44 \pm 0.25 \mathrm{a}$ & $3.42 \pm 0.05 \mathrm{~b}$ \\
Malonyldaidzin & $10.93 \pm 0.44 \mathrm{~b}$ & $11.13 \pm 0.41 \mathrm{~b}$ & $17.35 \pm 0.18 \mathrm{a}$ \\
Malonylglicitin & $7.31 \pm 1.02 \mathrm{~b}$ & $6.44 \pm 0.42 \mathrm{~b}$ & $11.51 \pm 0.59 \mathrm{a}$ \\
Malonylgenistin & $10.94 \pm 0.16 \mathrm{~b}$ & $10.65 \pm 0.28 \mathrm{bc}$ & $14.97 \pm 0.13 \mathrm{a}$ \\
Daidzein & $0.22 \pm 0.01 \mathrm{a}$ & Not detected & Not detected \\
\hline Total & $45.26 \pm 1.66 \mathrm{~b}$ & $44.66 \pm 0.68 \mathrm{~b}$ & $51.87 \pm 0.64 \mathrm{a}$ \\
\hline
\end{tabular}

${ }^{(1)}$ Expressed on a dry basis ( $\mathrm{mg}$ of isoflavones per $100 \mathrm{~g}^{-1}$ of sample). ${ }^{(2)} \mathrm{Brine}$ with $\mathrm{NaCl}_{2}, \mathrm{CaCl}_{2}$, citric acid, and zinc acetate; (3)brine with $\mathrm{NaCl}_{2}, \mathrm{CaCl}_{2}$, and citric acid. Mean values followed by equal letters, in the lines, do not differ by the Tukey's test, at $5 \%$ probability.

Table 4. Sugar content of vegetable-type soybean canned with zinc, or canned without zinc, or with fresh soybean grains.

\begin{tabular}{lccc}
\hline Sugar & $\begin{array}{c}\text { Canned } \\
\text { with zinc }^{(1)}\end{array}$ & $\begin{array}{c}\text { Control } \\
\text { (without zinc) }^{(2)}\end{array}$ & $\begin{array}{c}\text { Fresh } \\
\text { soybean grains }\end{array}$ \\
\hline Glucose & $0.14 \pm 0.05 \mathrm{~b}$ & $0.26 \pm 0.04 \mathrm{a}$ & $0.05 \pm 0.01 \mathrm{c}$ \\
Fructose & $0.12 \pm 0.04 \mathrm{~b}$ & $0.27 \pm 0.05 \mathrm{a}$ & $0.05 \pm 0.00 \mathrm{~b}$ \\
Sucrose & $1.06 \pm 0.02 \mathrm{c}$ & $1.51 \pm 0.05 \mathrm{~b}$ & $4.69 \pm 0.09 \mathrm{a}$ \\
Stachyose & $1.43 \pm 0.05 \mathrm{c}$ & $2.41 \pm 0.06 \mathrm{~b}$ & $5.03 \pm 0.01 \mathrm{a}$ \\
\hline
\end{tabular}

(1)Brine with $\mathrm{NaCl}_{2}, \mathrm{CaCl}_{2}$, citric acid, and zinc acetate. ${ }^{(2)}$ Brine with $\mathrm{NaCl}_{2}, \mathrm{CaCl}_{2}$, and citric acid. Mean values followed by equal letters, in the lines, do not differ by the Tukey's test, at $5 \%$ probability; results $\left(\mathrm{g} 100 \mathrm{~g}^{-1}\right)$ on a dry basis. that were observed in the present work involved the

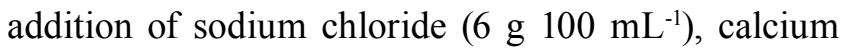

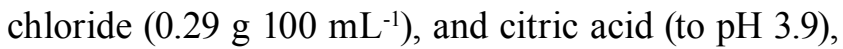
and pasteurization for $10 \mathrm{~min}$. According to Czaikoski et al. (2013), the addition of sucrose to the acidified brine also contributes to maintain the desirable color and soft texture of canned vegetable-type soybean grains.

\section{Conclusions}

1. The addition of zinc, in the limit of $\leq 75 \mathrm{ppm}$ of zinc in the final product (FDA), do not affect the physicochemical quality of canned grains, subjected to pasteurization for 10 minutes.

2. Thermal processing of the vegetable-type soybean grains in acidified brine containing zinc increases the content of isoflavone glycosides, decreases the content of malonylglycosides, and have lower-sucrose and stachyose contents, in comparison with those of fresh grains.

3. Microbiological analyzes show that canned vegetable-type soybeans are safe and can be consumed without any health risk.

4. The degree of chromatic hue of zinc-canned grains, in comparison to the control, is similar, which shows that the zinc addition do not significantly influences the coloring of grains.

\section{Acknowledgments}

To Fundação Araucária, to Conselho Nacional de Desenvolvimento Científico e Tecnológico (CNPq), and to Programa de Apoio a Núcleos de Excelência (Pronex) Program, for financial support.

\section{References}

ANDRADE, J.C.; MANDARINO, J.M.G.; KUROZAWA, L.E.; IDA, E.I. The effect of thermal treatment of whole soybean flour on the conversion of isoflavones and inactivation of trypsin inhibitors. Food Chemistry, v.194, p.1095-1101, 2016. DOI: 10.1016/j.foodchem.2015.08.115.

AOAC INTERNATIONAL. AOAC Official Method 941.03: Zinc in Plants. 20th ed. Gaithersburg: AOAC International, 2016.

ANVISA. Agência Nacional de Vigilância Sanitária. Informe Técnico n. 64, de 2 de dezembro de 2014. 2014. Available at: $<$ http://portal.anvisa.gov.br/documents/33916/388729/Informe+ $\mathrm{T} \% \mathrm{C} 3 \% \mathrm{~A} 9 \mathrm{cnico}+\mathrm{n} \% \mathrm{C} 2 \% \mathrm{BA}+64 \% 2 \mathrm{C}+\mathrm{de}+02+\mathrm{de}+$ dezembro + 
$\mathrm{de}+2014 / \mathrm{abc} 2 \mathrm{f} 745-3 \mathrm{c} 8 \mathrm{a}-4415-8 \mathrm{~b} 58-\mathrm{df} 512413 \mathrm{dbcf}>$. Accessed on: Sep. 22017.

BERHOW, M.A. Modern analytical techniques for flavonoid determination. In: BUSLIG, B.S.; MANTHEY, J.A. (Ed.). Flavonoids in cell function. New York: Springer, 2002. p.61-76. DOI: 10.1007/978-1-4757-5235-9_6.

CARRÃO-PANIZZI, M.C.; GOÉS FAVONI, S.P.; KIKUCHI, A. Extraction time for soybean isoflavone determination. Brazilian Archives of Biology and Technology, v.45, p.515-518, 2002. DOI: $10.1590 / \mathrm{S} 1516-89132002000600015$.

CZAIKOSKI, K.; LEITE, R.S.; MANDARINO, J.M.G.; CARRÃO-PANIZZI, M.C.; SILVA, J.B. da; IDA, E.I. Canning of vegetable-type soybean in acidified brine: Effect of the addition of sucrose and pasteurisation time on color and other characteristics. Industrial Crops and Products, v.45, p.472-476, 2013. DOI: 10.1016/j.indcrop.2012.09.009.

DAMODARAN, S.; PARKIN, K.L.; FENNEMA, O.R. Química de Alimentos de Fennema. 4.ed. Porto Alegre: Artmed, 2010.

DONG, X.; XU, W.; SIKES, R.A.; WU, C. Combination of low dose of genistein and daidzein has synergistic preventive effects on isogenic human prostate cancer cells when compared with individual soy isoflavone. Food Chemistry, v.141, p.1923-1933, 2013. DOI: 10.1016/j.foodchem.2013.04.109.

FEDERAL REGISTER. Canned green beans deviating from identity standard; extension and amendment of temporary permit for market testing. Federal Register, v.38, p.8708-8709, 1986.

FELLOWS, P.J. Food processing technology: principles and practices. $4^{\text {th }}$ ed. Florida: CRC Press, 2016. 1152p.

HOU, J.; WANG, C.; HONG, X.; ZHAO, J.; XUE, C.; GUO, N.; GAI, J.; XING, H. Association analysis of vegetable soybean quality traits with SSR markers. Plant Breeding, v.130, p.444449, 2011. DOI: 10.1111/j.1439-0523.2011.01852.x.

HSU, A.; BRAY, T.M.; HELFERICH, W.G.; DOERGE, D.R.; HO, E. Differential effects of whole soy extract and soy isoflavones on apoptosis in prostate cancer cells. Experimental Biology and Medicine, v.235, p.90-97, 2010. DOI: 10.1258/ebm.2009.009128.

KUDOU, S.; FLEURY, Y.; WELTI, D.; MAGNOLATO, D.; UCHIDA, T.; KITAMURA, K.; OKUBO, K. Malonyl isoflavone glycosides in soybean seeds (Glycine max Merrill). Agricultural and Biological Chemistry, v.55, p.2227-2233, 1991. DOI: 10.1271/bbb1961.55.2227.

LAWLESS, H.T.; HEYMANN, H. Sensory evaluation of food. New York: Chapman and Hall, 1998. 819p.

LIMA, F.S. de; KUROZAWA, L.E.; IDA, E.I. The effects of soybean soaking on grain properties and isoflavones loss. LWT - Food Science and Technology, v.59, p.1274-1282, 2014. DOI: 10.1016/j.lwt.2014.04.032.

MASUDA, R.; KANEKO, K.; YAMASHITA, I. Sugar and cyclitol determination in vegetables by HPLC using postcolumn fluorescent derivatization. Journal of Food Science, v.6, p.11861190, 1996. DOI: 10.1111/j.1365-2621.1996.tb10957.x.

MCGLYNN, W.G.; DAVIS, D.R.; HONARMAND, F. Gluconic acid influences texture and color of canned asparagus. Journal of Food Science, v.58, p.614-615, 1993. DOI: 10.1111/j.13652621.1993.tb04338.x.

MOZZONI, L.A.; MORAWICKI, R.O.; CHEN, P. Canning of vegetable soybean: procedures and quality evaluations. International Journal of Food Science and Technology, v.44, p.1125-1130, 2009. DOI: 10.1111/j.1365-2621.2009.01929.x.

NGO, T.; ZHAO, Y. Formation of zinc-chlorophyll-derivative complexes in thermally processed green pears (Pyrus communis L.). Journal of Food Science, v.72, p.C397-C404, 2007. DOI: 10.1111/j.1750-3841.2007.00465.x.

OLIVEIRA, A.P.V. de; FRASSON, K.; YAMASHITA, F.; BENASSI, M. de T. Medida instrumental de cor em sobremesa lácteas de chocolate: uma técnica de baixo custo e versátil utilizando câmara digital. Brazilian Journal of Food Technology, v.6, p.191-196, 2003.

OLIVEIRA, M.A. de; CARRÃO-PANIZZI, M.C.; MANDARINO, J.M.G.; LEITE, R.S.; CAMPOS FILHO, P.J. de; VICENTINI, M.B. Quantificação dos teores de açúcares, oligossacarídeos e amido em genótipos/cultivares de soja (Glycine $\max ($ L.) Merrill) especiais utilizados para alimentação humana. Brazilian Jornal of Food Technonology, v.13, p.23-29, 2010. DOI: 10.4260/BJFT2010130100004.

SACKS, L.G.; PORTUGUAL, A.P.; PRUDENCIO-FERREIRA, S.H.; FELINTO, A.S. Conversor em cor média RGB para imagens BMP. Available at: $<$ www. fflam.br $>$. Accessed on: May 152002.

SALDIVAR, X.; WANG, Y.-J.; CHEN, P.; HOU, A. Changes in chemical composition during soybean seed development. Food Chemistry, v.124, p.1369-1375, 2011. DOI: 10.1016/j. foodchem.2010.07.091.

SILVA, N. da; JUNQUEIRA, V.C.A.; SILVEIRA, N.F. de A.; TANIWAKI, M.H.; SANTOS, R.F.S. dos; GOMES, R.A.R. Manual de métodos de análise microbiológica de alimentos. 3.ed. São Paulo: Varela, 2007. 536p.

SUGIMOTO, M.; GOTO, H.; OTOMO, K.; ITO, M.; ONUMA, H.; SUZUKI, A.; SUGAWARA, M.; ABE, S.; TOMITA, M.; SOGA, T. Metabolomic profiles and sensory attributes of edamame under various storage duration and temperature conditions. Journal of Agricultural and Food Chemistry, v.58, p.8418-8425, 2010. DOI: $10.1021 /$ jf101471d.

WADA, K.; NAKAMURA, K.; TAMAI, Y.; TSUJI, M.; KAWACHI, T.; HORI, A.; TAKEYAMA, N.; TANABASHI, S.; MATSUSHITA, S.; TOKIMITSU, N.; NAGATA, C. Soy isoflavone intake and breast cancer risk in Japan: from the Takayama study. International Journal of Cancer, v.133, p.952960, 2013. DOI: 10.1002/ijc.28088.

WANG, C.C.R.; CHANG, S.K.C. Effect of selected canning methods on trypsin inhibitor activity, sterilization value, and firmness of canned navy beans. Journal of Agricultural and Food Chemistry, v.36, p.1015-1018, 1988. DOI: 10.1021/ jf00083a028.

YUE, X.; ABDALLAH, A.M.; XU, Z. Thermal dynamic properties of isoflavones during dry heating. International Journal of Food Science and Technology, v.45, p.1878-1882, 2010. DOI: 10.1111/j.1365-2621.2010.02346.x. 
XU, Y.; SISMOUR, E.; PAO, S.; RUTTO, L.; GRIZZARD, C.; REN, S. Textural and microbiological qualities of vegetable soybean (edamame) affected by blanching and storage conditions. Journal of Food Processing \& Technology, v.3, p.1-6, 2012. DOI: $10.4172 / 2157-7110.1000165$.
ZHENG, Y.; SHI, J.; PAN, Z.; CHENG, Y.; ZHANG, Y.; LI, $\mathrm{N}$. Effect of heat treatment, $\mathrm{pH}$, sugar concentration, and metal ion addition on green color retention in homogenized puree of Thompson seedless grape. LWT - Food Science and Technology, v.55, p.595-603, 2014. DOI: 10.1016/j.lwt.2013.10.011.

Received on May 8, 2017 and accepted on October 6, 2017 